\title{
Growth and yield of summer mungbean (SML-668) under different sowing methods in Ambala (Haryana)
}

\author{
GURU PREM, AFZAL AHMAD, VIKRAM. D SINGH, AMIT KUMAR, RAKESH CHOUDHARY \\ AND RAMESH KUMAR
}

Received : 10.03.2017; Revised : 09.07.2017; Accepted : 23.07 .2017

See end of the Paper for authors' affiliation

Correspondence to :

\section{GURU PREM}

Krishi Vigyan Kendra, AMBALA (HARYANA) INDIA Email : gpgrover79@gmail. com
-ABSTRACT : Field experiment was conducted at the farmers field of Ambala during year 2014 and 2015 to assess the growth and yield of summer mungbean in different sowing methods viz., $\left(\mathrm{T}_{1}\right)$ conventional tillage and broadcasting sowing method, $\left(\mathrm{T}_{2}\right)$ conventional tillage and line sowing and $\left(\mathrm{T}_{3}\right)$ zero tillage and line sowing. The line sowing and zero tillage sowing methods recorded higher plant height, number of pods per plant, number of seeds per pod and test weight during both the years. Sowing methods significantly affected the various growth parameter of summer mungbean crop. The seed yield under CT-line sowing and ZT-sowing was significantly 15 to 20 per cent higher than CT-broadcasting sowing method in the first year. During second year of the study, it was also significantly 14-19 per cent higher than $\mathrm{T}_{1}$-CT-broadcasting sowing method. Simultaneously, stover and biological yield $\left(\mathrm{kg} \mathrm{ha}^{-1}\right)$ and harvest index $(\%)$ were also recorded better value in $\mathrm{T}_{2}$ and $\mathrm{T}_{3}$ than $\mathrm{T}_{3}$. Due to the less cost of cultivation in ZT-sowing method, the $\mathrm{B}$ : $\mathrm{C}$ ratio was higher i.e. (2.16 and 2.18) as compared to (2.06 and 2.11) in CT-line sowing and (1.42 and 1.50) in CT-broadcasting during year 2014 and 2015, respectively.

- KEY WORDS : Summer mungbean, Sowing methods, Yield, Economics

- HOW TO CITE THIS PAPER : Prem, Guru, Ahmad, Afzal, Singh, Vikram. D., Kumar, Amit, Choudhary, Rakesh and Kumar, Ramesh (2017). Growth and yield of summer mungbean (SML-668) under different sowing methods in Ambala (Haryana). Internat. J. Agric. Engg., 10(2) : 275-279,

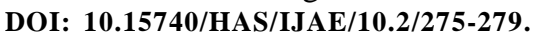

